Afr. J. Trad. CAM (2006) 3 (3): 70 - 75

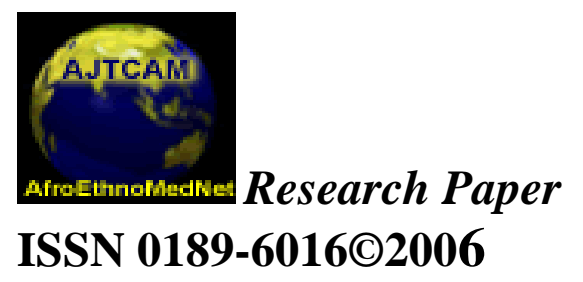

Afr. J. Traditional, Complementary and Alternative Medicines www.africanethnomedicines.net

\title{
PHYTOCHEMICAL SCREENING AND ANTIULCEROGENIC EFFECT OF MORINGA OLEIFERA AQUEOUS LEAF EXTRACT
}

\author{
*Dahiru, D., Onubiyi, J. A. and Umaru, H. A. \\ Department of Biochemistry Federal University of Technology, Yola \\ P.M.B. 2076, Yola, Adamawa State. \\ E-mail: ddahiru2000@yahoo.com
}

\begin{abstract}
The effect of aqueous extract of Moringa oleifera leaf was studied on experimentally induced gastric ulceration in rats. Pretreatment with extract 200, 300 and $400 \mathrm{mg} / \mathrm{kg}$ bw reduced the characteristic lesions induced by indomethacin compared to untreated control group in a dose dependent manner. The effects observed could be due to the action of one or more of the phytochemicals present in the leaf extract.
\end{abstract}

Key words: Moringa oleifera, peptic ulcer, phytochemicals.

\section{Introduction}

Moringa oleifera belongs to the family Asclepidaceae. It is commonly known in Hausa as Zogale, Kilba-Kabbi, and Fulani-Kabije. According to Harwell, (1971) the flowers are used as folk remedies for tumors, the seed for abdominal tumors, leaves applied as poultice to sores, rubbed on the temples of the head for headaches and said to have purgative properties. The leaves have been reported to have hypocholesterolemic effect (Ghasi, 2000); hepatoprotective effect on anti-tubercular drugs induced toxicity (Pari, 2002) and antimicrobial activities (Cacares, 1991).

Ulcer formation involves breaking the mucosal barrier and exposing the underlying tissue of the stomach or duodenal lining to the corrosive action of acid and pepsin (Vander, 1998). Numerous factors have been implicated in the pathogenesis of peptic ulcer disease, which may be acquired during life, although some of these may have already been predetermined (Ghasi, 2000).

Non-steroidal anti-inflammatory drugs are the commonest aetiological factor associated with peptic ulceration (Konturek et al., 1998). The deleterious effect of indomethacin on gastric duodenal mucosa is mainly attributed to direct damage of mucosal cell and its ability to reduce the formation of prostaglandins (Graham et al., 1995). The most common indomethacin induced adverse reaction is associated with the upper 


\section{Afr. J. Trad. CAM (2006) 3 (3): 70 - 75}

gastrointestinal tract and include subjective discomfort, ulcers and bleeding; the incidence of ulceration and bleeding occurs in a dose dependent fashion (Anthony et al., 1993).

The search for cheaper and readily available drugs for the treatment of ulcer necessitated the present study. We aimed to scientifically confirm the use of Moringa oleifera leaves in the treatment of ulcer as claimed in traditional medicine.

\section{Materials and Methods Plant material}

The leaves of Moringa oleifera were collected within Yola metropolis, Adamawa State in the month of April, 2004. The plant was authenticated by the Botany Department of Federal University of Technology, Yola and preserved in the Department of Biochemistry with a voucher number BC/FUTY/DD02/2004. The leaves were dried at room temperature and made in to powder using mortar and pestle.

\section{Preparation of aqueous leaf extract}

$50 \mathrm{~g}$ of the powdered leave were weighed and poured into $500 \mathrm{ml}$ conical flask in which 200ml of distilled water was added. The mixture was kept for 12 hours with constant agitation at 30 minutes intervals. The extract was filtered using Whatman No.1 filter paper. The filtrate was concentrated in vaccuo. The semi solid extract obtained was stored in a refrigerator for further use.

\section{Experimental animals}

White albino rats (male) weighing between 160-170g were used for the experiment. They were housed in steel cages at room temperature $30 \pm 2{ }^{\circ} \mathrm{C}$ under $12 / 12$ hours light dark cycle and were fed with pelleted standard feed (Vital Feeds Ltd., Jos) and water ad libitum.

\section{Treatment of animals}

The rats were randomised and divided into four groups of five rats each. Food was withdrawn 24hours and water 2hours before the commencement of experiment (Nwafor, 2000). Group I was administered with $100 \mathrm{mg} / \mathrm{kg}$ indomethacin (Shanghai Pham. \& Chem. Co. Ltd India). Groups II - IV were pre-treated with 200, 300 and 400mg/kg of extract respectively; 1 hour prior to administration of $100 \mathrm{mg} / \mathrm{kg}$ of indomethacin. The drugs were administered intragastrically via the aid of an orogastric cannula. Four hours later, the animals were killed after ether anaesthesia; the stomachs were removed and opened along the greater curvature. The tissues were fixed with $10 \%$ formaldehydesaline. Macroscopic examination was carried out with a hand lens and scored for the presence of lesions (Nwafor et al., 2000). 


$$
\text { Afr. J. Trad. CAM (2006) } 3 \text { (3: } 70 \text { - } 75
$$

Ulcer index (UI) and preventive ratio of each of the groups pre-treated with extract were calculated thus:

UI $=\quad \underline{\text { degree of ulceration } \mathrm{x} \text { percentage of group ulcerated }}$ 100

Preventive Ratio

Po = UI (Ulcerated group - protected group) $\times \underline{100}$

UI (Ulcerated group)

Degree of Ulceration $=\quad \underline{\text { Total Ulcer score }}$

No of animal Ulcerated

\section{Preliminary phytochemical analysis} (1994).

Phytochemical screening was carried out by the method described by Sofowora,

\section{Test for saponins}

Froth test for saponins was used. $1 \mathrm{~g}$ of the sample was weighed into a conical flask in which $10 \mathrm{ml}$ of sterile distilled water was added and boiled for $5 \mathrm{~min}$. The mixture was filtered and $2.5 \mathrm{ml}$ of the filtrate was added to $10 \mathrm{ml}$ of sterile distilled water in a test tube. The test tube was stopped and shaken vigorously for about 30second. It was then allowed to stand for half an hour. Honeycomb froth indicated the presence of saponins.

\section{Test for Tannins}

$3 \mathrm{~g}$ of the powdered sample was boiled in $50 \mathrm{ml}$ distilled water for 3minutes on a hot plate. The mixture was filtered and a portion of the filtrate diluted with sterile distilled water in a ratio of 1:4 and 3 drop of 10\% ferric chloride solution added. A blue or green colour indicates the presence of tannins.

\section{Test for phenol}

$2 \mathrm{ml}$ of extract was added to $2 \mathrm{mls}$ of ferric chloride solution $\left(\mathrm{FeCl}_{3}\right)$, a deep bluish green solution is formed with presence of phenols.

\section{Test for glycosides}

$25 \mathrm{ml}$ of dilute sulphuric acid was added to $5 \mathrm{ml}$ of extract in a test tube and boiled for 15 minutes, cooled and neutralized with $10 \% \mathrm{NaOH}$, then $5 \mathrm{ml}$ of fehling solution $\mathrm{A}$ and B was added. A brick red precipitate of reducing sugars indicates presence of glycosides. 
Afr. J. Trad. CAM (2006) 3 (3): 70 - 75

\section{Test for alkaloids}

$2.0 \mathrm{ml}$ of extract was measured in a test tube to which picric acid solution was added. The formation of orange coloration indicated the presence of alkaloids

\section{Test for volatile oils}

$2.0 \mathrm{ml}$ of extract solution was shaken with $0.1 \mathrm{ml}$ dilute sodium hydroxide and a small quantity of dilute $\mathrm{HCl}$. A white precipitate was formed with volatile oils.

\section{Test for hydrolysable tannins}

$4 \mathrm{ml}$ of the extract was shaken in a test tube, after which $4 \mathrm{ml}$ of $10 \%$ ammonia solution was added. Formation of an emulsion on shaking indicated the presence of hydrolysable tannins.

\section{Statistical analysis}

Results are presented as mean \pm S.E.M. Statistical analysis of the results was by Student's t-test.

\section{Results}

The results as presented in Table 1 below showed the pre-treatment with and without the aqueous leaf extract of Moringa oleifera on indomethacin gastric ulcerations. Administration of $100 \mathrm{mg} / \mathrm{kg}$ of indomethacin to the experimental control group significantly produced the characteristic necrotic lesion expected. The average lesion area was significantly lower in groups pre-treated with the extract at $200 \mathrm{mg} / \mathrm{kg}, 300 \mathrm{mg} / \mathrm{kg}$ (P $<0.005)$ and $400 \mathrm{mg} / \mathrm{kg}(\mathrm{P}<0.001)$.

The groups pre-treated with the various doses of the leave extract showed a progressive decline in ulcer indices relative to experimental control. The preventive ratio (percentage protection) conferred by the extract using the different doses was found to increase in a dose dependent manner.

Phytochemical screening of the leaf extract of Moringa oleifera revealed the presence of alkaloids, glycosides, phenols, saponins, tannins, volatile oils and hydrolysable tannins.

\section{Discussion}

Indomethacin is an established ulcerogenic agent especially in an empty stomach (John et al, 1990) mostly on the glandular (mucosal) part of stomach. It has been known that enzymes including cyclooxygenase and 5, 12 and 15 - lipooxygenase act on 


\section{Afr. J. Trad. CAM (2006) 3 (3): 70 - 75}

arachidonic acid and result in the production of inflammatory prostaglandin $E_{2}$ and thromboxane

Table 1: Effect of Moringa oleifera Leaf Extract on Indomethacin-Induced Ulceration in Rats

Treatment (mg/kg)

$100 \mathrm{mg} / \mathrm{kg}$ indomethacin

Only (control GP I)

200mg/kg extract (GP II)

$300 \mathrm{mg} / \mathrm{kg}$ extract (GP III)

400mg/kg extract (GP IV)

Results are mean + S.E.M,

Results are mean \pm S.E.M, $\mathrm{n}=5$. $* \mathrm{p}<0.05$ significant relative to control

${ }^{\mathrm{a}} \mathrm{p}<0.01$ significant relative to GP II, ${ }^{\mathrm{b}} \mathrm{p}<0.001$ significant relative to GP III.

(Aguwa and Nwanko, 1998). Synthesis of prostaglandin is important due to the fact that prostaglandin normally serve a protective function in stomach by inactivating gastric microcirculation and cause gastric secretion of bicarbonate and mucus (Vander, 1998).

High anti-inflammatory doses of indomethacin have been found to interfere with the synthesis of proteoglycans by chondrocytes, transmembrane ion fluxes, and cell to cell binding. It also has the ability to unmask T-cell suppressor activity that may lead to a reduction in the rheumatoid factor (Nwafor et al., 2000). The aqueous extract of Moringa oleifera leaf was shown to protect rats from developing gastric ulcer induced by indomethacin in a dose dependently manner.

It has been proposed that mucosal protection induced by non-prostaniod compounds may be mediated through the mobilization of endogenous prostaglandins (Cho et al., 1983: Konturek et al., 1987 and Nwafor et al., 2000). Prostaglandins are potent mediator of inflammation that result in oedema, pain and vasodilation, it also influence other mediator of inflammation including the synthesis of leukotrienes, superoxide generation and lysozomal enzyme release. Prostaglandin $\mathrm{E}_{2}$ protect the gastric mucosa from acid damage by maintaining adequate blood flow (Caceres et al, 1991),

Tannins with its protein precipitating and vasoconstriction effect could be advantageous in preventing ulcer development (Aguwa et al., 1988). Tannins being an astringent may have precipitated microproteins on the site of the ulcer thereby forming an impervious protective pellicle over the lining to prevent toxic substance and resist the attack of proteolytic enzyme (John and Onabanjo, 1990).

Presence of flavonoids have been reported to offer some protection in ulcer development by increasing capillary resistance, and improve microcirculation which renders the cells less injurious to precipitating factors (Caceres et al, 1991). 


\section{Afr. J. Trad. CAM (2006) 3 (3):70 - 75}

The leaf extract was found to protect the gastric mucosa against indomethacin effect in a dose dependent manner. Phytochemical constituent of the leaf extract of Moringa oleifera (tannins and flavonoids) that reduced initiation and perpetuation of ulceration may be responsible for the observed effects. The leaf extract thus has the potential of an altiulcerogenic agent, which suggest it's used in traditional medicine.

Further work should be carried out to isolate, purify and possibly characterize the active principle responsible for the observed effect. Also additional work should be embarked upon with a view to elucidate the possible mechanism of action of the extract.

\section{References}

1. Aguwa, C.N. and Nwanko, S.O. (1988). Preliminary studies on the root extract of Naulea latifolia Smith, for antiulcer properties. Nig. J. Pharmaceutical Sci. 4(1): 16 - 23.

2. Anthony, A. Dhillon, A.P. and Nygard, G. (1993). Early Histological Features of Small Intestinal Injury Induced by Indomethacin. J. Aliment Pharmacol Therapy; 7: 29 - 40.

3. Caceres, A.B; Cabrera, O; Mirals, O. Mollinedo, O. and Imendia, A. (1991).Preliminary screening for antimicrobial activity of Moringa oleifera. J. Ethnopharmacol. 33: 213 - 216.

4. Cho, C.H; Hua, M.F; Chou, C.K. and Hot, T. (1983). Protection of zinc sulphate against necrosis induced by ethanol in rats. Proceeding Netherlands Science Council Royal Society, (7): $261-267$.

5. Ghasi, S. and Nwabodo, E. (2000). Hypocholesterolemic effect of crude leaf of Moringa oleifera in high fat diet fed Wister rats; J. Ethnopharmacol. 69 (1): 21 - 25.

6. Graham, D. Y; Smith, J. L. and Opekum, P. A. (1995). Spicy food and the stomach. Journal AM Medical Association; 260: 3473 - 3475.

7. $\quad$ Harwell, J. L. (1971). Plants used against cancer: A Survey. Lloydia 1: 30 - 34.

8. John, T.A. and Onabanjo, A. O. (1990). Gastroprotective effect of an aqueous extract of Entandro phragmautile bark in experimental ethanol-induced peptic ulceration in mice and rats. J. Ethnopharmacol. 29: 87 - 93.

9. Konturek, S.J; Redeck, T; Plastuck, I; Brzozowski, T. and Drodowicz, D. (1998). Gastroprotection by collidal bismuth substrate (Denol) and sucralfate: Role of endogenous prostaglandin. Gut, 228 : $201-205$.

10. Nwafor, A; Paul, F; Okwasaba, K. and Binda, L.G (2000). Anti diarrhoeal and antiulcerogenic effect of methanolic extract of Asparagus pubescens root in rats. J. Ethnopharmacol .72 : $421-427$

11. Pari, L. and Kumar, N.A. (2002). Hepatoprotective Activity of Moringa oleifera on Anti tubercular drug induce liver damage in rats. J. Medicinal Food, 5 (3): 171 - 177

12. Sofowora, E.A. (1994). Medical Plant and Traditional Medicine in Africa. University of Ife Press, Nigeria: pp. 1 - 23.

13. Vander, S.L. (1998). Human Physiology $7^{\text {th }}$ edn. Oxford University Press, New York: pp. 583. 